\title{
Pengaruh Salah Pilih Jurusan Terhadap Rasa Putus Asa Mahasiswa Teknik Informatika
}

\author{
Imamul Arifin S,Sy. M.H. \\ Politeknik Elektronika Negeri Surabaya \\ E-mail: imamul@pens.ac.id \\ Wahyu Primayasa \\ Politeknik Elektronika Negeri Surabaya \\ E-mail: yasaprima2000@gmail.com \\ Muhammad Yusuf Baharsyah \\ Politeknik Elektronika Negeri Surabaya \\ E-mail: stazcblog@gmail.com
}

\begin{abstract}
Abstrak
Teknik Informatika adalah salah satu jurusan yang paling dibutuhkan di era digital saat ini. Banyak calon mahasiswa baru yang tertarik untuk melanjutkan pendidikan dengan kuliah di jurusan Teknik Informatika. Akan tetapi, banyak dari calon mahasiswa yang menentukan pilihan ini secara terburu buru tanpa informasi dan pertimbangan yang mendalam. Hal ini mengakibatkan beberapa mahasiswa merasa salah memilih jurusan ketika mereka sudah memasuki bangku kuliah. Tujuan dari penelitian ini adalah untuk mengetahui pengaruh dari salah pilih jurusan terhadap rasa putus asa yang dialami para mahasiswa. Hasil penelitian menunjukkan bahwa hampir 50\% mahasiswa teknik informatika merasa tidak cocok dengan jurusan teknik informatika serta merasa salah jurusan. Akibatnya banyak diantara mereka merasa putus asa dengan perkuliahan mereka.
\end{abstract}

Kata Kunci: mahasiswa, salah jurusan, putus asa.

\begin{abstract}
Informatics Engineering is one of the most needed majors in the current digital era. Many prospective new students are interested in continuing their education by studying in the Department of Information Engineering. However, many prospective students make these choices in a hurry without detailed information and consideration. This caused some students to feel wrong choosing their majors when they entered college. The purpose of this study was to determine the effect of the choice of department majors on the despair experienced by students. The results showed that almost $50 \%$ of informatics engineering students did not feel comfortable with the department of informatics engineering and felt the wrong direction. As a result, many of them feel hopeless with their lectures.
\end{abstract}

Keywords: students, wrong majors, desperate.

\section{PENDAHULUAN}

Teknik Informatika merupakan salah satu jurusan pendidikan tingkat perguruan tinggi yang mempelajari serta menerapkan prinsipprinsip ilmu komputer dan analisis matematis dalam perancangan, pengujian, pengembangan, dan evaluasi sistem operasi, perangkat lunak (software), dan kinerja computer (Nimda, 2019). Pada zaman ini, jurusan ini adalah salah satu jurusan yang sangat dibutuhkan dan memiliki prospek karier yang bagus kedepannya dikarenakan kebutuhan teknologi informasi sangatlah tinggi.

Dengan fakta fakta yang ada, banyak calon mahasiswa tertarik dan ingin masuk ke jurusan teknik informatika ini. Disisi lain, para orang tua terkadang juga menyarankan anaknya untuk masuk dalam jurusan ini dikarenakan prospeknya yang bagus. Namun, yang disayangkan adalah banyak dari mereka memilih jurusan ini diputuskan secara tergesa gesa tanpa didasari dengan pengetahuan dan 
informasi yang mendalam ataupun hanya sekedar mengikuti tren yang ada. Pemilihan jurusan yang tergesa gesa ini dapat berakibat fatal bagi para mahasiswa baru. Ketika mereka memasuki bangku kuliah, banyak mereka menyadari bahwa mereka mempelajari sesuatu yang tidak sesuai minat, bakat dan kemampuan mereka.

Memilih jurusan kuliah yang sesuai dengan minat sangatlah penting. Hal ini dikarenakan minat adalah rasa lebih suka dan rasa ketertarikan pada suatu hal atau aktifitas tanpa ada yang menyuruh.(Slameto, 2015). Dengan memilih jurusan yang sesuai dengan minat maka mereka akan dapat menjalaninya dengan penuh rasa suka dan antusias. Sebaliknya, penentuan jurusan yang salah dapat menjadi academic stressor bagi mahasiswa (Rahmawati, 2017). Academic stersor ini dapat mimicu reaksi terhadap pikiran, prilaku, reaksi tubuh dan perasaan mahasiswa. (Rahmadani, 2014). Reaksi yang muncul pada perasaan mahasiswa yang umum terjadi adalah munculnya persasaan cemas, murung dan putus asa.

Dengan adanya fenomena diatas, penulis ingin mengkaji dan menganalisis korelasi antara salah jurusan dengan meningkatnya rasa putus asa pada mahasiswa.

\section{METODE}

Pada penelitian ini partisipan adalah mahasiswa Teknik Informatika. Partisipan berjumlah 16 orang mahasiswa yang terdiri dari 11 mahasiswa laki laki dan 5 mahasiswa perempuan.

Data dalam penelitian ini dikumpulkan dengan menggunakan metode survey. Survey dibuat dengan menggunakan aplikasi Google Form yang disebarkan menggunakan media social kedalam grup grup mahasiswa teknik informatika. Partisipan diminta untuk membaca dan memilih pilihan yang ada.

Data yang didapat diolah dengan menggunakan metode kuantitatif. Data ditampilkan dengan menggunakan diagram diagram untuk memudahkan analisa. Analisa data dilakukan dengan pendekatan deskriptif korelasioanal untuk mengetahui hubungan antar data data yang ada.

\section{HASIL DAN PEMBAHASAN Hasil}

Berikut ini adalah data yang didapat dari survey yang telah dilakukan. Data jenis kelamin dari partisipan ditampilkan dalam grafik dibawah ini.

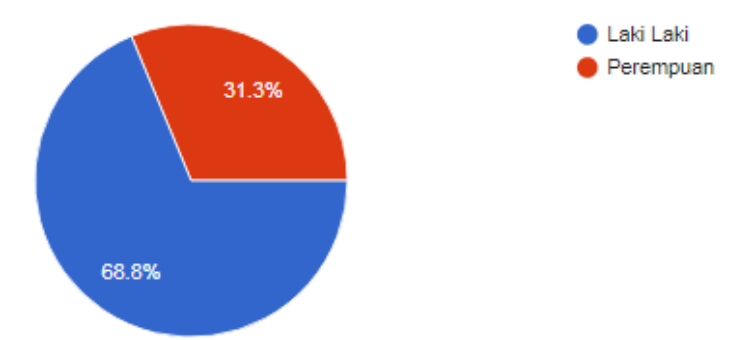

Grafik 1. Data Jenis Kelamin Responden

Berdasarkan grafik 1. Jumlah partisipan laki laki adalah sebnayak $68.8 \%$ dan perempuan sebanyak $13.5 \%$. Dari grafik ini dapat diketahui bahwa mahasiswa Teknik Informatika didominasi oleh mahasiswa laki laki.

Berikut ini adalah data dari tingkat pengetahuan ( mengenal ) jurusan teknik informatika.

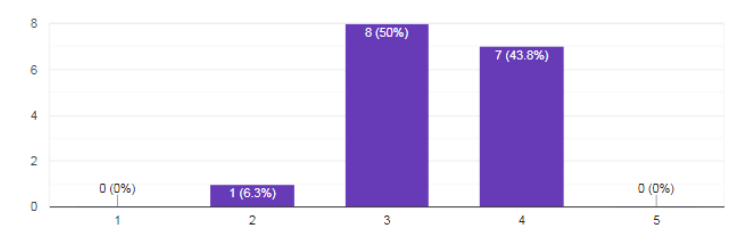

Grafik 2. Tingkat Pengetahuan ( mengenal ) Jurusan Teknik Informatika

Berdasarkan grafik 2. 6.3\% partisipan hanya mengenal jurusan teknik informatika dengan tingkat 2 dari 5 (40\%). 50\% mahasiswa mengenal dengan tingkat $60 \%$. $43.8 \%$ mahasiswa mengenal dengan tingkat $80 \%$. Dari grafik ini dapat diketahui bahwa sebagian besar mahasiswa teknik informatika kurang mengenal 
jurusan yang mereka pilih. Bahkan ada diantaranya yang mengenal kurang dari $50 \%$

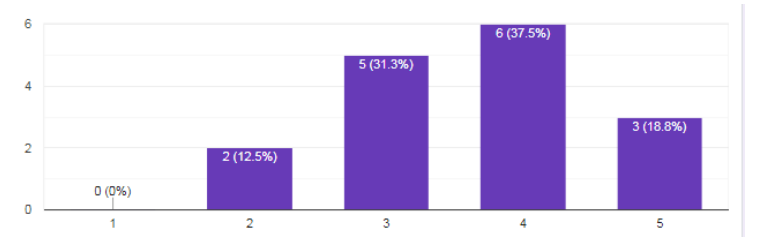

Grafik 3. Tingkat Kecocokan dengan Jurusan Teknik Informatika

Berdasarkan grafik 3. $12.5 \%$ partisipan menyatakan bahwa tingkat kecocokan mereka dengan jurusan ini hanya hanya 40\%. 31.3\% partisipan menyatakan bahwa tingkat kecocokan mereka adalah $60 \%$. $37.5 \%$ partisipan menyatakan bahwa tingkat kecocokan mereka adalah $80 \%$. $18.8 \%$ partisipan menyatakan bahwa tingkat kecocokan mereka adalah $100 \%$. Dari data ini dapat diketahui bahwa hampir 50\% mahasiswa teknik informatika merasa tidak cocok dan salah salah memilih jurusan teknik informatika.

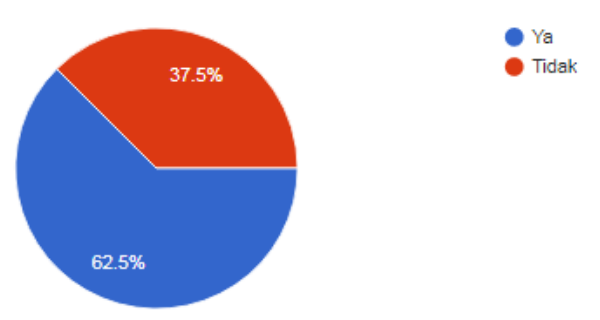

Grafik 4. Mahasiswa yang Merasa Putus Asa

Berdasarkan grafik 4. $62.5 \%$ partisipan menyatakan bahwa mereka merasa putus asa terhadap kehidupan kuliah mereka dan $37.5 \%$ persen dari paetisipan tidak merasa putus asa. Dari grafik ini dapat dikatahui bahwa hamper 2/3 mahasiswa teknik informatika merasa putus asa dengan kuliah mereka.

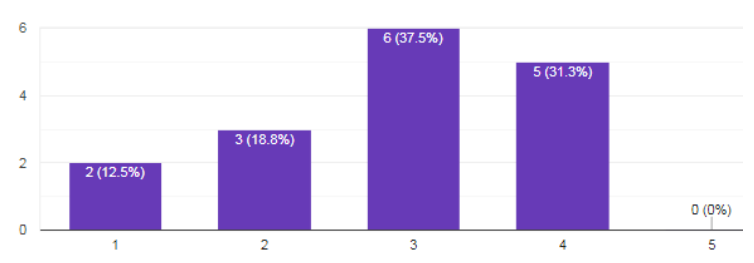

Grafik 5. Tingkat Semangat Mahasiswa Mengikuti Perkuliahan

Berdasarkan grafik 5. $12.5 \%$ partisipan menyatakan bahwa mereka memiliki tingkat semangat mengikuti perkuliahan sebesar $1 / 5$ atau $20 \%$. $18.8 \%$ memiliki tingat semangat 40\%. $37.5 \%$ memiliki tingat semangat $60 \%$. $31.2 \%$ memiliki tingat semangat $80 \%$.
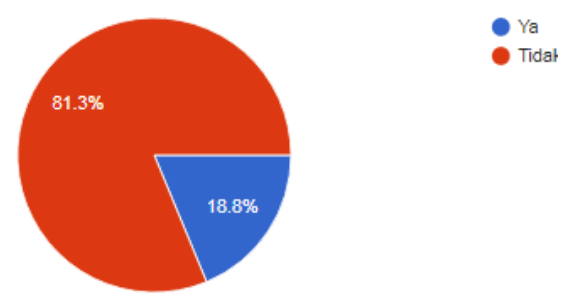

Grafik 6. Presentase Mahasiswa yang ingin Pindah Jurusan

Berdasarkan grafik 6. $18.8 \%$ partisipan menyatakan bahwa mereka ingin pindah dari jurusan Teknik Informatika. Sedangka sisanya $(81.3 \%)$ tidak ingin pindah dari jurusan teknik informatika.

\section{Pembahasan}

Dari survey yang telah dilakukan diketahui bahwa hampir $50 \%$ mahasiswa teknik informatika merasa tidak cocok dan merasa salah memilih jurusan. Hasil ini sejalan dengan survey survei Indonesia Career Center Network (ICCN) pada 2017, 87 persen mahasiswa Indonesia mengaku salah jurusan. Angka ini tentulah jumlah yang sangat besar.

Kesalahan dalam memilih jurusan dapat berakibat pada munculnya rasa putus asa dan stress pada mahasiswa. (Barseli, 2017) Berdasarkan hasil survey dikatahui bahwa $62.5 \%$ mahasiswa merasa putus asa dengan perkuliahan yang sedang mereka tempuh. Rasa 
kecewa dan putus asa yang dialami oleh para mahasiswa ini adalah adalah sifat tercela yang dapat berakibat fatal. Rasa putus asa akan mengakibatkan orang yang mengalaminya menjadi merasa hilang arah dan tujuan. Allah taala berfirman:

$$
\text { قَالَ وَمَنْ يَقْنَطُ مِنْ رَحْمَةِ رَبِّهِ إِلَّا الضََّالُّنَ }
$$

"Ibrahim berkata : 'Tidak ada orang yang berputus asa dari rahmat Rabbnya, kecuali orang-orang yang sesat."” [QS. Al Hijr: 56]

Bahkan, pada kondisi yang parah. Sikap putus asa dapat mengakibatkan seseorang terjerus pada kekafiran. Allah taala berfirman:

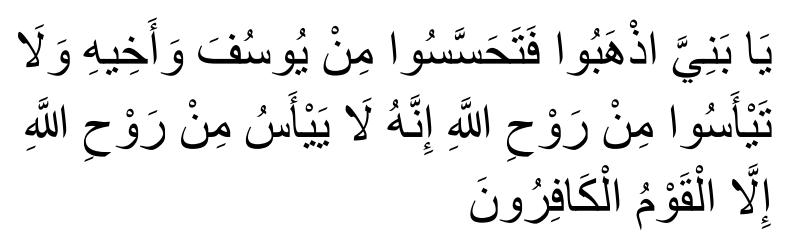

Artinya: "Wahai anak-anakku, pergilah kalian dan carilah berita mengenai Yusuf dan saudaranya, dan janganlah kalian berputus asa dari rahmat Allah. Sesungguhnya tidaklah ada yang berputus asa dari rahmat Allah kecuali orang-orang kafir.” [QS. Yusuf: 87]

Selain itu putus asa dapat mengakibatkan berbagai dampak negative. Stres dan putus asa dapat mengaikbatkan gelaja emosional dan fisik (Hernawati, 2006). Gejala fisik yang dialamai dapat berupa sakit kepala, pusing, susdah tidur, perubahan pola makan. Putus asa juga dapat mengakibatkan kesulitan mengambil keputusan, gangguan menejemen diri, menghindari tanggung jawab dan ketidak hadiran / turn over. (Nurlaila, 2017). Lebih lanjut, hasil survey juga menunjukkan hal yang serupa bahwa para mahasiswa yang mengalami putus asa menjadi malas untuk mengikuti kegiatan perkuliahan. Selain itu sebagian mahasiswa yang mengalami putus asa juga memiliki keinginan yang kuat untuk pindah jurusan.

\section{PENUTUP}

\section{Simpulan}

Berdasarkan hasil survey dan analisis yang telah dilakukan, dapat diketahui bahwa terdapat korelasi antara kesalahan dalam pemilihan jurusan dengan meningkatnya rasa putus asa pada mahasiwa teknik informatika. Sebagian besar mahasiswa yang merasa tidak cocok dan salah memilih jurusan memilki kecenderungan merasa kecewa dan putus asa dengan perkuliahannya.

Hasil penelitian menunjukkan $12.5 \%$ partisipan menyatakan bahwa tingkat kecocokan mereka dengan jurusan ini hanya hanya $40 \%$. $31.3 \%$ partisipan menyatakan bahwa tingkat kecocokan mereka adalah 60\%. $37.5 \%$ partisipan menyatakan bahwa tingkat kecocokan mereka adalah $80 \%$. $18.8 \%$ partisipan menyatakan bahwa tingkat kecocokan mereka adalah $100 \%$. Dari data ini dapat disimpulkan bahwa hampir $50 \%$ mahasiswa teknik informatika merasa tidak cocok dan salah salah memilih jurusan teknik informatika.

Hasil penelitian juga menunjukkan bahwa 62.5 $\%$ persen mahasiswa merasa putus asa dengan perkuliahan yang sedang dijalani dikarenakan mereka merasa salah memilih jurusan.

\section{Saran}

Berdasarkan penelitian, pembahasan, dan kesimpulan maka penulis akan memberikan beberapa saran yang diharapkan dapat bermanfaat bagi pihak lain.

\section{Calon Mahasiswa Baru}

Para calon mahasiswa diharapakan dapat melakukan pencarian informasi dan melakukan pertimbangan matang matang sebelum memutuskan untuk memilih suatu jurusan sebagai pedidikan lanjutannya. Hal ini dikarenaka sebuah jurusan yang terkanal serta 
memiliki prospek kerja yang bagus belum tentu cocok bagi para calon mahasiswa baru.

2. Mahasiswa

Bagi mahasiswa telah terlanjur memilih program studi teknik informatika dan merasa putus asa diharapkan mempertimbangan beberapa pilihan yang ada yaitu pindah jurusan atau tetap bertahan dengan tetap semangat dan optimistis. Semua pilihan memliki konsekuensi yang juga harus dipertimbankan dengan matang..

\section{DAFTAR PUSTAKA}

Barseli, M,. \& Ifdhil, I. 2017. Konsep Stress Akademik Siswa. Jurnal Konseling dan Pendidikan, 5, 143-148.

Hernawati, N. 2006. Tingkat stres dan strategi koping menghadapi stres pada mahasiswa Tingkat Persiapan Bersama tahun akademik 2005/2006. Jurnal Ilmu Pertanian Indonesia, 11(2), 43-49.

Jawapos.com 2019. Mahasiswa Mengaku Salah Jurusan, Banyak Sarjana yang Penting Lulus. Jawapos.com. Diambil dari https://www.jawapos.com/nasional/pendidik an/15/12/2019/mahasiswa-mengaku-salahjurusan-banyak-sarjana-yang-pentinglulus//penyebab-ciri-depresi-pada-remaja/ (diakses tanggal 1 Mei 2020)

Nurlaila, N. 2017. Kompensasi Beban dalam Persfektif Psikologi Islam . Tadrib, 2(1), 96122.

Nimda. 2019. Mengenal Jurusan Teknik Informatika. unpas.ac.id. Diambil dari https://www.teknik.unpas.ac.id/blogs/menge nal-jurusan-teknik-informatika/ (diakses tanggal 20 Maret 2020)

Rahmadani, C. S. M. 2014. Hubungan antara Sense of Humor dengan Stress Akademik pada Siswa Kelas Akselerasi SMA Negeri 1 Bireun (Doctoral dissertation, Universitas Medan Area)

Rahmawati, W. K. 2017. Efektivitas Teknik Restrukturisasi Kognitif untuk Menangani
Stres Akademik Siswa. Jurnal Konseling Indonesia, 2(1).

Slameto. 2015. Belajar dan Faktor-faktor yang Mempengaruhinya.Jakarta: Rineka Cipta 